\section{Socio-demographic determinants of self-rated health in Brazil}

\author{
Determinantes sócio-demográficos \\ da auto-avaliação da saúde no Brasil
}

Célia Landmann Szwarcwald 1 Paulo Roberto Borges de Souza-Júnior 1 Maria Angela Pires Esteves 1 Giseli Nogueira Damacena 1 Francisco Viacava 1

\footnotetext{
1 Centro de Informação Científica e Tecnológica, Fundação Oswaldo Cruz, Rio de Janeiro, Brasil.

Correspondence C. L. Szwarcwald Departamento de Informações em Saúde, Centro de Informação Científica e Tecnológica, Fundação Oswaldo Cruz. Av. Brasil 4365, Rio de Janeiro, $R J$ 21045-900, Brasil. celials@cict.fiocruz.br
}

\begin{abstract}
Self-rated health has been used extensively in epidemiologic studies, not only due to its importance per se but also due to the validity established by its association with clinical conditions and with greater risk of subsequent morbidity and mortality. In this study, the socio-demographic determinants of good self-rated health are analyzed using data from the World Health Survey, adapted and carried out in Brazil in 2003. Logistic regression models were used, with age and sex as covariables, and educational level, a household assets index, and work-related indicators as measures of socioeconomic status. Besides the effects of sex and age, with consistently worst health perception among females and among the eldest, the results showed pronounced socioeconomic inequalities. After adjusting for age, among females the factors that contributed most to deterioration of health perception were incomplete education and material hardship; among males, besides material hardship, work related indicators (manual work, unemployment, work retirement or incapable to work) were also important determining factors. Among individuals with long-term illness or disability, the socioeconomic gradient persisted, although of smaller magnitude.
\end{abstract}

Health Status; Socioeconomic Survey; Epidemiologic Studies

\section{Introduction}

Self-rated health has been used extensively in epidemiologic studies to gauge a population's state of health 1 . Considered a useful measure due to its easy accessibility in population surveys, self-rated health has been used to establish differences in morbidity between population subgroups, to compare health service and resource needs between geographical areas, and to calculate morbi-mortality indicators, such as healthy life expectancy 2,3 .

Although an individual's "objective" health state, from a medical point of view, refers to a pathologic abnormality indicated by an assemblage of signs and symptoms, self-evaluation is subjective, combining physical and emotional components, including sense of wellbeing and satisfaction with life. The state of feeling sick does not refer exclusively to feelings of physical pain and discomfort, but also to the psychological and social consequences of having a problem 4 .

The individual perception of health is, thus, an important indicator per se, since an individual's level of wellbeing can influence, relatively, his motivation and quality of life. Besides, the utility of self-rated health also derives from its validity derived from its relationship to clinical conditions and to indicators of morbidity and mortality 5,6.

Research has demonstrated that the perception of health appears to be reasonably re- 
alistic, agreeing with the doctor's evaluation of state of health 7 . In addition, studies indicate that the perception of precarious health may occur in the absence of apparent sickness at the time, but also be an important factor in predicting health problems that only later will be detected 4,8 . This independent prediction of health through self-evaluation suggests that there exist preclinical feelings of sickness that manifest before the medical identification of illness 9 .

In terms of mortality, since 1982, when pioneering research proved the association between self-evaluation of poor health and increased risk of death among the elderly 10 , a significant number of studies have demonstrated that the perception of poor health is an important factor for subsequent mortality 11,12,13, even after controlling the effects of "objective" indicators of health states established in medical registers 14 .

The existence of socioeconomic inequalities in health has been evidenced as much in industrialized countries 15,16 as in developing countries $17,18,19$. The results of worldwide investigations generally show that health indicators vary according to a social gradient unfavorable to groups of lower socioeconomic levels, whether this be measured by income, education, occupation, or social class 20,21,22,23.

Evidence that self-rated health varies according to socioeconomic status is found in recent international literature. Lack of education, material hardship, inferior social position, and work situation have been shown to be important determinants in the perception of bad health $24,25,26,27$.

Using data from the World Health Survey, a population study carried out in Brazil in 2003, the present study seeks to identify the socioeconomic determinants of self-evaluations of good health in Brazil.

\section{Methods}

As part of a project elaborated by the World Health Organization (WHO) aimed at evaluating the performance of member countries' health systems, the World Health Survey was realized in Brazil in 2003. It surveyed five thousand individuals 18 years of age or greater. The project was approved by the Research Ethics Committee of the Fundação Oswaldo Cruz in December, 2002.
The sample design had three stages of selection. In the first stage, 250 census tracts were systematically selected, with probability proportional to size, excluding special sectors, such as military installations, penitentiaries, asylums, and indigenous reserves. Size of municipality (<50,000;50,000-399,999; 400,000+ population) and urban/rural situation explicitly stratified the primary sampling units. The mean income of the household head in each census tract was used for implicit stratification. In the second stage, households were selected with equiprobability using an inverse sample design to assure 20 interviews by sector. In each household, just one adult (18 years or more) was selected with equiprobability to respond to the individual questionnaire. One household member was identified to respond to questions relative to household characteristics, assets and expenditures. The sample weights were based on the inverse of probabilities of inclusion in the sample calculated for each selection stage.

For the statistical analysis, data were treated in accordance with the selection design using the SUDAAN software program (version 7.5).

Analysis of general state of health was based on the following question: "In general, how would you rate your health today"? Responses varied on a scale of 1 to 5 ( $1=$ very bad; 2 = bad; 3 = moderate; 4 = good; 5 = very good).

Analyses were done using age groups (1829 ; 30-44; 45-59; 60+ years), sex, and socioeconomic status. To examine disparity by socioeconomic status, three variables were considered: degree of education (primary education incomplete, primary education complete, middle school complete or better); household assets; and work situation.

The measure of socioeconomic level by the presence of household assets was done using the household assets indicator (HAI), an index calculated by:

$$
I B=\sum_{i}\left(1-f_{i}\right) b_{i}
$$

where $i$ varies from 1 to 10 assets; $b_{i}$ is equal to 1 or zero, respectively, in the presence or absence of television, refrigerator, stereo, fixed telephone, washing machine, cellular telephone, automobile, microwave oven, computer, or dishwasher. The weight attributed to the presence of each domestic asset was the complement of the relative frequency $\left(f_{i}\right)$ of each asset in the total sample, that is, the rarer the pres- 
ence of an item in the household, the greater the weight attributed to the item.

With regard to the work situation, individuals were first categorized among those who have or have no paid work. In the first group, the individuals were classified as manual workers (farmer or fisherman, skilled or unskilled laborer) and non-manual workers (high-level professional, high government or business employee, middle-level professional, administrative servant or employee, commercial employee). In the second group, individuals were classified as: housewife; unemployed (looked for, but did not find work); retired or incapable to work; other (student, unpaid worker).

In the first phase of analysis, the distribution of self-rated health scores was analyzed by sex and age. The subjective perception of state of health was compared to another indicator of selfreported morbidity, the presence of long-term illness or disability, also asked in the questionnaire (“Do you have a long-term illness or disability?").

Subsequently, using stepwise logistic regression models, the socioeconomic determinants of self-evaluation of good health (scores $4=\operatorname{good}$ or $5=$ very good) were identified for each sex. At each step, likelihood ratio statistics were used to choose variables, using the $5.0 \%$ level of significance as criterion for inclusion and $10.0 \%$ for exclusion. The models were successively applied for each group of individuals, including those reporting the presence of longterm disease or disability and those that do not.

\section{Results}

Among the 4,997 interviewees that self-evaluated their health, 9.0\% evaluated their health as "bad" or "very bad," $53.0 \%$ as "good" or "very good," and $38.0 \%$ as "moderate". The perception of health was worse among females when compared to males: the percentage of selfevaluation "good" or "very good" was $47.0 \%$ for females and $60.0 \%$ males. The percentage of selfevaluation "good" or "very good" varied greatly by age group, ranging from $28.0 \%$ among individuals 60 or more years old, to $70.0 \%$, among youth between 18 and 29 years old (Table 1).

The data in Table 2 show variation in health perception "good" or "very good" by degree of education. The lower the level of education, the lower the percentage, varying from $41.0 \%$, among interviewees with incomplete primary education, to $72.0 \%$, among those who completed middle school or greater, including in this category those individuals with university education, corresponding to $6.2 \%$ of the total sample.
In general, the pattern encountered is of worse perception of health among the eldest, among females when compared to males in any age group, and among those of lower education levels relative to those of higher education levels. In addition, the social gradient in "good" or "very good" self-rated health repeats for each age group or sex (Table 2).

Analysis of the data presented in Table 3 shows that only $27.0 \%$ of individuals that reported a long-term disease or disability perceived their health to be "good" or "very good," whereas among individuals that did not report an illness, this percentage is $64.0 \%$. These differences are reproduced for both sexes and for all age groups, with self-rated health being worse in the case of long-term disease or disability. Nevertheless, it is important to note that $4.0 \%$ of individuals that did not report long-term disease or disability self-evaluated their health as "bad" or "very bad."

Analysis of data by work situation indicates that almost half $(49.0 \%)$ of individuals 18 years old or more did not have paid work. Among females, this percentage is $63.0 \%$, and among males, $33.0 \%$. The difference is explained by the greater proportion of female housewives. In general, $11.0 \%$ claimed to be looking for work without success (unemployed), with little difference between sexes. Among people with paid work, about $57.0 \%$ are manual workers, $35.0 \%$ middle-level professionals, and $8.0 \%$ high-level professionals.

In relation to the distribution of individuals by the presence of household assets, the most commonly encountered item is a television (91.8\%), followed by refrigerator $(89.9 \%)$ and stereo $(78.2 \%)$. Assets with proportions varying from $30.0 \%$ to $60.0 \%$ include fixed telephone (57.4\%), washing machine $(56.4 \%)$, cellular telephone $(37.9 \%)$ and automobile (35.1\%). The most infrequently encountered assets were microwave oven $(21.3 \%)$, computer $(15.6 \%)$ and dishwasher (4.8\%). The relative frequencies described here serve as a basis for calculating the HGI, as explained in the Methods section.

Presented in Table 4 are the results of logistic regression models using "good" or "very good" self-rated health as dependent variable, applied separately for each sex. Model I considers the inequalities by educational level, controlling for the effect of age. It shows that differences in level of education, when compared to those with middle education completed, are significant for both sexes, although the gradient is more pronounced for females. Using middle school completed as the control category, the odds-ratio (OR) among females with 
Table 1

Distribution (\%) of individuals by self-evaluation of health state, according to age group and sex. Brazil, 2003.

\begin{tabular}{|c|c|c|c|c|c|c|c|}
\hline \multirow[t]{2}{*}{ Sex } & \multirow{2}{*}{$\begin{array}{l}\text { Age group } \\
\text { (years) }\end{array}$} & \multicolumn{5}{|c|}{ Self-rated health (\%) } & \multirow[t]{2}{*}{ Sample size } \\
\hline & & Very good & Good & Moderate & Bad & Very bad & \\
\hline \multirow[t]{5}{*}{ Females } & $18-29$ & 16.5 & 48.2 & 31.0 & 3.8 & 0.5 & 819 \\
\hline & $30-44$ & 12.2 & 40.3 & 40.0 & 5.4 & 2.1 & 874 \\
\hline & $45-59$ & 6.5 & 25.7 & 52.0 & 10.3 & 5.5 & 642 \\
\hline & $60+$ & 4.5 & 19.5 & 53.6 & 16.0 & 6.4 & 373 \\
\hline & Total & 11.1 & 36.3 & 42.0 & 7.5 & 3.0 & 2,708 \\
\hline \multirow[t]{5}{*}{ Males } & $18-29$ & 28.4 & 46.9 & 21.4 & 2.9 & 0.4 & 716 \\
\hline & $30-44$ & 18.5 & 46.3 & 30.6 & 3.1 & 1.4 & 712 \\
\hline & $45-59$ & 13.3 & 40.0 & 36.7 & 7.6 & 2.4 & 489 \\
\hline & $60+$ & 8.0 & 23.3 & 49.1 & 15.8 & 3.8 & 368 \\
\hline & Total & 18.8 & 41.4 & 32.0 & 6.1 & 1.7 & 2,285 \\
\hline \multirow[t]{5}{*}{ Total } & $18-29$ & 22.1 & 47.6 & 26.5 & 3.3 & 0.5 & 1,530 \\
\hline & $30-44$ & 15.1 & 43.0 & 35.8 & 4.3 & 1.8 & 1,587 \\
\hline & $45-59$ & 9.4 & 31.9 & 45.5 & 9.1 & 4.1 & 1,133 \\
\hline & $60+$ & 6.3 & 21.4 & 51.4 & 15.8 & 5.1 & 747 \\
\hline & Total & 14.6 & 38.7 & 37.5 & 6.8 & 2.4 & 4,997 \\
\hline
\end{tabular}

Table 2

Percentage (\%) of individuals with good/very good self-rated health, according to age group, sex, and educational level. Brazil, 2003.

\begin{tabular}{llcccc}
\hline Sex & $\begin{array}{l}\text { Age group } \\
\text { (years) }\end{array}$ & $\begin{array}{c}\text { Primary school } \\
\text { incomplete }\end{array}$ & $\begin{array}{c}\text { Educational level } \\
\text { Primary school } \\
\text { complete and middle } \\
\text { school incomplete }\end{array}$ & $\begin{array}{c}\text { Middle school } \\
\text { complete }\end{array}$ & Total \\
\hline Females & $18-29$ & 51.5 & 64.0 & 75.9 & 64.7 \\
& $30-44$ & 39.6 & 54.4 & 73.2 & 52.5 \\
& $45-59$ & 25.2 & 39.7 & 51.8 & 32.2 \\
Males & $60+$ & 22.2 & 33.3 & 36.7 & 24.1 \\
& Total & 33.9 & 55.1 & 69.4 & 47.5 \\
& $18-29$ & 65.8 & 78.4 & 83.0 & 75.2 \\
Total & $30-44$ & 57.8 & 65.3 & 76.8 & 64.9 \\
& $45-59$ & 45.3 & 61.5 & 68.5 & 31.4 \\
& $60+$ & 27.9 & 45.8 & 45.1 & 60.2 \\
& Total & 49.4 & 69.8 & 75.3 & 69.6 \\
& $18-29$ & 58.5 & 71.1 & 78.9 & 58.1 \\
& $30-44$ & 47.8 & 59.4 & 74.8 & 41.3 \\
& $45-59$ & 33.5 & 50.5 & 60.1 & 27.7 \\
& $60+$ & 24.9 & 39.6 & 42.0 & 53.3 \\
\hline
\end{tabular}


Table 3

Distribution (\%) of individuals by self-evaluation of health state, according to age group,

sex, and presence of long-term disease or disability. Brazil, 2003.

\begin{tabular}{|c|c|c|c|c|c|}
\hline \multirow{2}{*}{$\begin{array}{l}\text { Presence of long-term } \\
\text { disease or disability }\end{array}$} & \multirow[t]{2}{*}{ Sex } & \multirow{2}{*}{$\begin{array}{l}\text { Age group } \\
\text { (years) }\end{array}$} & \multicolumn{3}{|c|}{ Self-rated health } \\
\hline & & & Very good/good & Moderate & Bad/very bad \\
\hline \multirow[t]{15}{*}{ No } & Females & $18-29$ & 69.4 & 27.2 & 3.4 \\
\hline & & $30-44$ & 61.5 & 34.8 & 3.6 \\
\hline & & $45-59$ & 44.3 & 47.0 & 8.7 \\
\hline & & $60+$ & 32.9 & 58.2 & 8.9 \\
\hline & & Total & 58.7 & 36.4 & 5.0 \\
\hline & Males & $18-29$ & 77.8 & 19.5 & 2.7 \\
\hline & & $30-44$ & 72.2 & 25.8 & 2.0 \\
\hline & & $45-59$ & 67.2 & 30.6 & 2.2 \\
\hline & & $60+$ & 47.5 & 45.2 & 9.1 \\
\hline & & Total & 70.4 & 26.6 & 3.1 \\
\hline & Total & $18-29$ & 73.5 & 23.5 & 3.1 \\
\hline & & $30-44$ & 63.3 & 30.8 & 2.9 \\
\hline & & $45-59$ & 55.4 & 39.2 & 5.4 \\
\hline & & $60+$ & 40.0 & 51.3 & 8.7 \\
\hline & & Total & 64.3 & 31.7 & 4.0 \\
\hline \multirow[t]{15}{*}{ Yes } & Females & $18-29$ & 42.3 & 48.9 & 8.8 \\
\hline & & $30-44$ & 24.4 & 56.0 & 19.6 \\
\hline & & $45-59$ & 18.5 & 57.4 & 24.2 \\
\hline & & $60+$ & 17.2 & 50.7 & 32.1 \\
\hline & & Total & 23.5 & 54.0 & 22.5 \\
\hline & Males & $18-29$ & 55.0 & 36.3 & 8.8 \\
\hline & & $30-44$ & 40.8 & 47.1 & 12.1 \\
\hline & & $45-59$ & 27.2 & 47.9 & 24.9 \\
\hline & & $60+$ & 15.6 & 52.6 & 31.8 \\
\hline & & Total & 31.3 & 47.4 & 21.3 \\
\hline & Total & $18-29$ & 47.2 & 44.0 & 9.7 \\
\hline & & $30-44$ & 31.3 & 52.2 & 16.5 \\
\hline & & $45-59$ & 21.7 & 54.1 & 24.2 \\
\hline & & $60+$ & 16.5 & 51.7 & 31.8 \\
\hline & & Total & 26.6 & 51.4 & 22.0 \\
\hline
\end{tabular}

primary education incomplete is 0.30 and, among males, 0.41 , even after adjusting for age.

The results of model II show positive effect of the HAI (calculated as explained in the Methods section), suggesting better health evaluation among more affluent people, even when controlling for the effects of degree of education and age (Table 4). It is worth noting that for males, the HAI was more important than level of education for explaining the socioeconomic gradient of self-rated health.

Model III considers, additionally, the effects of work situation. Divergent results were encountered between the sexes (Table 4). Among females, the issue of work is not significant, re- gardless of the indicators included in the model. Among males, work situation is fundamental. Together with the HAI, the variables relative to work situation explained the observed socioeconomic gradient, rendering the effect of degree of education nonsignificant. The results of model III indicate the significant negative effects of the categories of male manual workers, the unemployed, and the retired incapable to work, when compared to the category of non-manual laborers.

Model III was applied, separately, to the groups established by the presence or absence of long-term disease or disability, for each sex (Table 5). Among individuals that do not have 
Results of multivariate logistic regression models with very good or good self-rated health as dependent variable.

\begin{tabular}{|c|c|c|c|c|c|}
\hline \multirow{3}{*}{ Variable } & & \multicolumn{4}{|c|}{ Model I } \\
\hline & & \multicolumn{2}{|c|}{ Females } & \multicolumn{2}{|c|}{ Males } \\
\hline & & $\operatorname{Exp}(b)$ & $95 \% \mathrm{Cl}$ & $\operatorname{Exp}(b)$ & $95 \% \mathrm{Cl}$ \\
\hline Age & & $0.969 * *$ & $0.96-0.98$ & $0.968^{\star \star}$ & $0.96-0.97$ \\
\hline \multirow[t]{3}{*}{ Educational level } & Primary school incomplete & $0.304^{\star \star}$ & $0.24-0.38$ & $0.410 * \star$ & $0.31-0.54$ \\
\hline & Middle school incomplete & $0.532^{\star \star}$ & $0.40-0.71$ & $0.691 * \star$ & $0.49-0.97$ \\
\hline & Middle school complete & 1.000 & - & 1.000 & - \\
\hline \multirow[t]{3}{*}{ Variable } & & \multicolumn{4}{|c|}{ Model II } \\
\hline & & \multicolumn{2}{|c|}{ Females } & \multicolumn{2}{|c|}{ Males } \\
\hline & & $\operatorname{Exp}(b)$ & $95 \% \mathrm{Cl}$ & $\operatorname{Exp}(b)$ & $95 \% \mathrm{Cl}$ \\
\hline Age & & $0.964^{\star *}$ & $0.96-0.97$ & $0.965^{\star \star}$ & $0.96-0.97$ \\
\hline \multirow[t]{3}{*}{ Educational level } & Primary school incomplete & $0.458^{\star \star}$ & $0.37-0.57$ & $0.584^{\star \star}$ & $0.42-0.81$ \\
\hline & Middle school incomplete & $0.655^{\star \star}$ & $0.49-0.87$ & $0.830 * *$ & $0.58-1.18$ \\
\hline & Middle school complete & 1.000 & - & 1.000 & - \\
\hline Household assets indicator & & $1.372^{\star \star}$ & $1.26-1.49$ & $1.248^{\star \star}$ & $1.11-1.40$ \\
\hline \multirow[t]{3}{*}{ Variable } & & \multicolumn{4}{|c|}{ Model III } \\
\hline & & \multicolumn{2}{|c|}{ Females } & \multicolumn{2}{|c|}{ Males } \\
\hline & & $\operatorname{Exp}(b)$ & $95 \% \mathrm{Cl}$ & $\operatorname{Exp}(b)$ & $95 \% \mathrm{Cl}$ \\
\hline Age & & $0.968^{\star \star}$ & $0.96-0.98$ & $0.968^{* *}$ & $0.96-0.98$ \\
\hline \multirow[t]{3}{*}{ Educational level } & Primary school incomplete & $0.476^{\star \star}$ & $0.37-0.61$ & 0.710 & $0.50-1.01$ \\
\hline & Middle school incomplete & $0,657^{\star *}$ & $0.49-0.88$ & 0.985 & $0.68-1.44$ \\
\hline & Middle school complete & 1.000 & - & 1.000 & - \\
\hline Household assets indicator & & $1.346^{\star \star}$ & $1.23-1.47$ & $1.177^{\star \star}$ & $1.04-1.33$ \\
\hline \multirow[t]{5}{*}{ Work } & Non-manual worker & 1.000 & - & 1.000 & - \\
\hline & Manual worker & 0.884 & $0.63-1.24$ & $0.547^{\star \star}$ & $0.39-0.76$ \\
\hline & Housewife & 0.862 & $0.66-1.13$ & - & - \\
\hline & Unemployed & 0.946 & $0.66-1.36$ & $0.586^{*}$ & $0.39-0.89$ \\
\hline & Retired/Disabled & 0.701 & $0.46-1.07$ & $0.4524^{* *}$ & $0.30-0.68$ \\
\hline
\end{tabular}

* p-value $<5.0 \%$;

$\star *$ p-value $<1.0 \%$

a long-term disease, the results of the model changed little. For both sexes, the socioeconomic determinants of self-evaluation of good health remained the same. Among females, the determinants remained degree of education and the HAI. Among males, they remained the HAI and work situation, expressed by unskilled labor and unemployment. Among individuals with long-term disease, the socioeconomic inequalities of health self-evaluation are less pronounced. For females, only incomplete primary education and the HAI contribute significantly. For males, only the manual work categories and retired or incapacitated status contribute significantly, since the HAI and degree of education loose statistical significance.

\section{Discussion}

The results of this study clearly show an association between sociodemographic factors and self-evaluation of good health in the Brazilian population. The findings are consistent with those encountered in developed countries 6,28.

Disparities between the sexes are well documented in the international literature 29. As found in the present study, females, in general, evaluate their own state of health lower than males do, despite females on average living longer lives than males. The principal explanation given for this worse perception of health state is the role played by females in society, whereby they acknowledge pain and discomfort more easily than males do 30,31. The dis- 
Socio-demographic determinants of good or very good self-rated health, according to presence or absence of long-term disease or disability.

\begin{tabular}{|c|c|c|c|c|c|}
\hline \multirow[t]{3}{*}{ Variable } & & \multirow{2}{*}{\multicolumn{4}{|c|}{ Among individuals without long-term disease or disability }} \\
\hline & & & & & \\
\hline & & $\operatorname{Exp}(b)$ & $95 \% \mathrm{Cl}$ & $\operatorname{Exp}(b)$ & $95 \% \mathrm{Cl}$ \\
\hline Age & & $0.970 * *$ & $0.96-0.98$ & $0.970 * \star$ & $0.96-0.98$ \\
\hline \multirow[t]{3}{*}{ Educational level } & Primary school incomplete & $0.470 * \star$ & $0.34-0.65$ & 0.710 & $0.45-1.11$ \\
\hline & Middle school incomplete & $0.653^{\star}$ & $0.45-0.94$ & 1.119 & $0.70-1.78$ \\
\hline & Middle school complete & 1.000 & - & 1.0000 & - \\
\hline Household assets indicator & & $1.413^{\star \star}$ & $1.26-1.58$ & $1.255^{\star \star}$ & $1.07-1.47$ \\
\hline \multirow[t]{4}{*}{ Work } & Non-manual worker & 1.000 & - & 1.0000 & - \\
\hline & Manual worker & 0.969 & $0.64-1.46$ & $0.607 * \star$ & $0.43-0.85$ \\
\hline & Housewife & 0.803 & $0.58-1.11$ & - & - \\
\hline & Unemployed & 0.854 & $0.56-1.30$ & $0.555^{\star}$ & $0.34-0.90$ \\
\hline \multirow[t]{2}{*}{ Variable } & & \multicolumn{4}{|c|}{$\begin{array}{l}\text { Among individuals with long-term illness or disability } \\
\text { Females }\end{array}$} \\
\hline & & $\operatorname{Exp}(b)$ & $95 \% \mathrm{Cl}$ & $\operatorname{Exp}(b)$ & $95 \% \mathrm{Cl}$ \\
\hline Age & & 0.987 & $0.97-1.00$ & $0.969^{\star \star}$ & $0.95-0.99$ \\
\hline \multirow[t]{3}{*}{ Educational level } & Primary school incomplete & $0.495^{\star}$ & $0.29-0.85$ & 0.873 & $0.48-1.57$ \\
\hline & Middle school incomplete & 0.681 & $0.35-1.32$ & 0.812 & $0.40-1.65$ \\
\hline & Middle school complete & 1.000 & - & 1.000 & - \\
\hline Household assets indicator & & $1.375^{\star \star}$ & $1.16-1.62$ & 1.098 & $0.91-1.33$ \\
\hline \multirow[t]{5}{*}{ Work } & Non-manual worker & 1.000 & - & 1.000 & - \\
\hline & Manual worker & 0.694 & $0.33-1.48$ & $0.401 * \star$ & $0.22-0.74$ \\
\hline & Housewife & 0.856 & $0.46-1.59$ & - & - \\
\hline & Unemployed & 1.137 & $0.48-2.68$ & 0.778 & $0.29-2.12$ \\
\hline & Retired/Disabled & 0.845 & $0.43-1.68$ & $0.398 * \star$ & $0.20-0.79$ \\
\hline
\end{tabular}

* p-value $<5.0 \%$

** $p$-value $<1.0 \%$

tinct nature of adult life, including less female participation in the paid work marketplace, is another reason cited in the literature 32.

Age is also shown to be a relevant factor. Given that the majority of illnesses are more prevalent among the elderly, self-evaluation of health usually worsens with advanced age 6,28.

In the United States, results of the National Health Survey, realized in the year 2000 33, show that $12.0 \%$ of North Americans perceive their health as "bad" or "very bad" and $64.0 \%$ evaluate their own health as "good" or "very good." The percentage of people who self-evaluate negatively is a bit larger than that obtained for the Brazilian population, $9.0 \%$, most likely being explained by the larger number of elderly people in the American population. The percentage of positive self-evaluation in the United States was 11 percentage points greater than that in Brazil, expressing a better perception of wellbeing in the North American population.
Despite the differences in distribution of self-rated health scores among North Americans, the pattern of behavior by sex, age, and socioeconomic condition was similar to that encountered in Brazil. In the United States, the percentage of good self-rated health is lower for females $(62.0 \%)$ than for males $(66.0 \%)$, decreasing with age and socioeconomic level. Considering annual household income, the percentage of positive self-evaluation varied from $80.0 \%$, among those earning US $\$ 75,000$ or more, to $47.0 \%$, among those earning less than US $\$ 20,00033$.

Socioeconomic inequalities in self-reported morbidity were also identified in studies carried out in Europe. A recent study showed pronounced social gradients in eleven European countries (Belgium, Denmark, France, Germany, Great Britain, Greece, Ireland, Italy, Holland, Portugal, and Spain), being based in three health indicators: self-evaluation of state of health, limitation of activities due to a health 
problem, and long-term illness or disability. Invariably, the results were less favorable the worse the social condition of the individual 15.

Among indicators of socioeconomic level, education probably has been the most used, since it is a stable attribute in adult life, in contrast to occupational and income statuses, which can vary with time 28 . However, equally important factors in predicting perception of bad health included living in a poor area, being socially disadvantaged, having precarious work conditions, having an inferior occupational situation, or lacking job security 24,27,34,35.

In Brazil, studies involving health self-rated health are scarcer, but nevertheless have consistently shown the socioeconomic gradient. In one study based on data from the National Survey by Household Sample from 1998 (PNAD1998), the elderly with lower income demonstrated lower health perceptions, had some of their daily activities compromised by health problems, and complained of difficulties accomplishing physical activities with higher frequency 36 . Another study using the PNAD-1998 data showed, similarly, differences in self-rated health state in accord to levels of income and education 37 .

In the present analysis, the possession of assets was, markedly, a big factor contributing to the perception of satisfactory health, as much among females as among males. Following the discussion by Martikainen et al. 26, this wealth indicator does not only reflect the material necessities of life, such as possibility of securing good nutrition and adequate habitation, and is also a social marker of wellbeing.

In relation to the other socioeconomic determinants of self-evaluation of good health, important differences were encountered between the sexes. For males, the work situation, including type of occupation and unemployment, as well as possession of material assets, were essential factors for explaining the differences in health perception between socioeconomic levels. For females, incomplete education and material hardship were the most strongly associated variables.

The finding that work situation affects the distinction between sexes is supported by the results of studies from other countries: although factors related to work appear to make the greatest contribution in explaining socioeconomic differentiation between males, family structure is more important among females 38,39 . One explanation for differences by sex is in the low proportion of females with paid work 40 , as occurs in Brazil. Whereas for males, paid work is essential for social wellbeing, for females, the quality of life does not depend on work alone, but also on the support of a companion or family in providing the necessities for material comfort.

Among males, the explanation for the effects of work situation on the perception of health depends on the disequilibrium between large work effort and low rewards, where rewards include salary, self-esteem, and career opportunities, including job security 5 . The results obtained in the present analysis corroborate this model: unskilled labor and unemployment were determinants for bad perception of health. In the case of males with long-term disease or disability, unskilled labor was also a factor associated with self-evaluation of bad health. In view of the social context and the disturbances to daily activities caused by the illness, the degree of suffering experienced by the patient may be much more intense for a manual worker than for a non-manual worker, and result, consequently, in a lower evaluation of health 4 .

The utility of self-rated health derives from its validity, reflected, in part, by its relationship to clinical conditions and indicators of morbidity and mortality 41 . There is also evidence of its ability to foretell important clinical responses, which exceed the scope of objective indicators 11,42 . The results obtained here suggest that individuals with long-term disease or disability have a worse self-evaluation of health than their peers of the same age group and sex. Yet, this condition was not sufficient to establish a bad perception of health. Reciprocally, it shows that a small portion $(4.0 \%)$ self-evaluate their health as bad, even in the absence of long-term disease or disability, which may be reflecting inequality in access to diagnosis of chronic diseases.

Recently, published studies have sought to infer an association between the perception of bad health and morbi-mortality. One investigation in the United States analyzed the relationship between the perception of health state and subsequent mortality among the North American adult population (21 years or more) during a period of five years. Adjusting for sociodemographic factors (age, sex, education, household income, and race), self-evaluation of bad health was significantly associated with elevated rates of mortality 6 .

Various theories have been advanced to explain the predictive power of self-rated health in relation to future morbidity and mortality. Primarily, bad health perception may be an indication of the health-illness process, still undetectable biologically or medically 41 . In an- 
other important explanation, self-rated health involves the individual's own familiarity with a wide variety of factors influential in his or her own life, such as: risk behavior, family history of illness, family longevity, among others 43. An alternative hypothesis is that self-rated health reflects quality of life, or sociodemographic and psychosocial conditions that may have adverse effects on health. However, with regard to stratification by socioeconomic status, study in Sweden evidenced that mortality relative risks calculated for individuals with good self-rated health relatively to those with bad health perception were similar in all socioeconomic groups 13 .

Just as the utility of self-rated health measurement is grounded in its subjective character, paradoxically, so are its limitations: hypochondriacs or people who worry a lot about health tend to self-evaluate worse than is justified by their actual states of health 44,45 ; aspects of individual personality, such as optimism (or pes- simism), appear to affect the perception of health 46; the concept of good health can be interpreted distinctly, in terms of the absence or presence of a health problem, of general physical functionality, or of cultural patterns of healthy behavior 47 .

The precarious perception of one's own health can be seen, therefore, as the result of suffering pain or discomfort in interaction with social, cultural, psychological, and environmental factors, all of which modify the manner in which one's life is affected by health problems. Consequently, it should be analyzed in multidimensional scope, taking into consideration different individual understandings of health in front of the cultural and psychosocial context and social rupture evolved. The results of the present study suggest that in Brazil, age, sex, material wellbeing, degree of education, and work status (among males) are relevant dimensions.
Resumo

A auto-avaliação da saúde vem sendo amplamente utilizada nos estudos epidemiológicos, não só por ser importante por si, mas também pela sua validade, estabelecida por suas relações com as condições clínicas e com o maior risco de morbi-mortalidade subseqüente. Neste trabalho, são analisados os determinantes sócio-demográficos da auto-avaliação de saúde boa, utilizando os dados da Pesquisa Mundial de Saúde, inquérito domiciliar realizado no Brasil, em 2003. Foram utilizados modelos de regressão logística, considerando idade e sexo como co-variáveis, e o grau de instrução, a posse de bens no domicílio e a situação de trabalho como indicadores do nível sócio-econômico. Além das diferenças por sexo e idade, com auto-avaliações consistentemente piores entre as mulheres e entre os mais idosos, os resultados indicaram acentuadas desigualdades sócio-econômicas. Ajustando-se por idade, entre as mulheres, a instrução incompleta e a privação material foram os fatores que mais contribuíram para a pior percepção da saúde; entre os homens, além da privação material, os indicadores relacionados ao trabalho tiveram efeitos importantes. Entre os indivíduos com doença de longa duração ou incapacidade, o gradiente social persistiu, embora em menor magnitude.

Nível de Saúde; Enquete Sócio-econômica; Estudos Epidemiológicos

\section{Contributors}

C. L. Szwarcwald designed the article's content, participated in the data analysis and drafting of the article, and coordinated the research. P. R. B. Souza-Júnior was in charge of the data analysis and supervised the research in some regions. M. A. P. Esteves participated in the drafting of the article and the literature review. G. N. Damacena participated in the data analysis and elaboration of the tables. F. Viacava participated in drafting the article and served as substitute research coordinator.

\section{Acknowledgements}

The present study had the financial support of the World Health Organization, the Conselho Nacional de Desenvolvimento Científico e Tecnológico (CNPq; National Counsel for Scientific Development and Technology), and the Departamento de Ciência e Tecnologia (DECIT; Department of Science and Technology), Ministério da Saúde (Ministry of Health). 


\section{References}

1. Gold M, Franks P, Erickson P. Assessing the health of the nation. The predictive validity of a preference-based measure and self-rated health. Med Care 1996; 34:163-77.

2. Devlin N, Hansen P, Herbison P. Variations in selfreported health status: results from a New Zealand survey. N Z Med J 2000; 113:517-20.

3. Kind P, Dolan P, Gudex C, Williams A. Variations in population health status: results from a United Kingdom national questionnaire survey. BMJ 1998; 316:736-41.

4. Blank N, Diderichsen F. The prediction of different experiences of long-term illness: a longitudinal approach in Sweden. J Epidemiol Community Health 1996; 50:156-61.

5. Pikhart H, Bobak M, Siegrist J, Pajak A, Rywik S Kyshegyi J, et al. Psychosocial work characteristics and self rated health in four post-communist countries. J Epidemiol Community Health 2001; 55:624-30.

6. Franks P, Gold MR, Fiscella K. Sociodemographics, self-rated health, and mortality in the US. Soc Sci Med 2003; 56:2505-14.

7. Hunt SM, McKenna SP, McEwen J, Backett EM, Williams J, Papp E. A quantitative approach to perceived health status: a validation study. J Epidemiol Community Health 1980; 34:281-6.

8. Kaplan GA, Goldberg DE, Everson SA, Cohen RD, Salonen R, Tuomilehto J, et al. Perceived health status and morbidity and mortality: evidence from the Kuopio ischaemic heart disease risk factor study. Int J Epidemiol 1996; 25:259-65.

9. Froom P, Melamed S, Triber I, Ratson N, Hermoni D. Predicting self-reported health: the CORDIS study. Prev Med 2004; 39:419-23.

10. Mossey JM, Shapiro E. Self-rated health: a predictor of mortality among the elderly. Am J Public Health 1982; 72:800-8

11. Idler EL, Benyamini Y. Self-rated health and mortality: a review of twenty-seven community studies. J Health Soc Behav 1997; 38:21-37.

12. Kaplan GA, Camacho T. Perceived health and mortality: a nine-year follow-up of the human population laboratory cohort. Am J Epidemiol 1983; 117:292-304.

13. Burstrom B, Fredlund P. Self rated health: is it as good a predictor of subsequent mortality among adults in lower as well as in higher social classes? J Epidemiol Community Health 2001; 55:836-40.

14. Leung KK, Tang LY, Lue BH. Self-rated health and mortality in Chinese institutional elderly persons. J Clin Epidemiol 1997; 50:1107-16.

15. Mackenbach JP, Kunst AE, Cavelaars AEJM, Gronhof F, Geurts JJM. Socioeconomic inequalities in morbidity and mortality in Western Europe. The EU Working Group on Socioeconomic Inequalities in Health. Lancet 1997; 349:1655-9.

16. Macintyre S. The Black Report and beyond: what are the issues? Soc Sci Med 1997; 44:723-45.

17. Braveman P, Tarimo E. Social inequalities in health within countries: not only an issue for affluent nations. Soc Sci Med 2002; 54:1621-35.

18. Schneider MC, Castillo-Salgado C, Loyola-Elizondo E, Bacallao J, Mujica OJ, Vidaurre M, et al.
Trends in infant mortality inequalities in the Americas: 1955-1995. J Epidemiol Community Health 2002; 56:538-41.

19. Victora CG, Vaughan JP, Barros FC, Silva AC, Tomasi E. Explaining trends in inequalities: evidence from Brazilian child health studies. Lancet 2000; 356:1093-8.

20. Adler N, Boyce WT, Chesney MA, Folkman S, Syme SL. Socioeconomic differences in health: no easy solution. JAMA 1993; 269:3140-5.

21. Chandola T. Social class differences in mortality using the new UK National Statistics Socio-Economic Classification. Soc. Sci Med 2000; 50:641-9.

22. Knust AE, Geurts JJM, van den Berg J. International variation in socioeconomic inequalities in self reported health. J Epidemiol Community Health 1995; 49:117-23.

23. Marmot M, Ryff CD, Bumpass LL, Shipley M, Marks NF. Social inequalities in health: next questions and converging evidence. Soc Sci Med 1997; 44:901-10

24. Borg V, Kristensen TS. Social class and self-rated health: can the gradient be explained by differences in life style or work environment? Soc Sci Med 2000; 51:1019-30.

25. Cavelaars AE, Kunst AE, Geurts JJ, Crialesi R, Grotvedt L, Helmert U, et al. Differences in self reported morbidity by educational level: a comparison of 11 western European countries. J Epidemiol Community Health 1998; 52:219-27.

26. Martikainen P, Adda J, Ferrie JE, Smith GD, Marmot M. Effects of income and health on GHQ depression and poor self rated health in white collar females and males in the Whitehall II study. J Epidemiol Community Health 2003; 57:718-23.

27. Ferrie JE, Shipley MJ, Marmot MG, Stansfeld S, Smith GD. Health effects of anticipation of job change and non-employment: longitudinal data from the Whitehall II study. BMJ 1995; 311:1264-9.

28. Heistaro S, Vartiainen E, Puska P. Trends in selfrated health in Finland 1972-1992. Prev Med 1996; 25:625-32.

29. Denton M, Prus S, Walters V. Gender differences in health: a Canadian study of the psychological, structural and behavioral determinants of health. Soc Sci Med 2004; 58:2585-600.

30. Verbrugge LM. Sex differentials in health. Public Health Rep 1982; 97:417-37.

31. Gijsbers-van Wijk CM, van Vliet KP, Kolk AM, Everaerd WT. Symptom sensitivity and sex differences in physical morbidity: a review of health surveys in the United States and The Netherlands. Females Health 1991; 17:91-124.

32. Emslie C, Hunt K, Macintyre S. Problematizing gender, work and health: the relationship between gender, occupational grade, working conditions and minor morbidity in full-time bank employees. Soc Sci Med 1999; 48:33-48.

33. Pleis JR, Schiller JS, Benson V. Summary health statistics for U.S. adults: National Health Interview Survey, 2000. Vital Health Stat 10 2003; (215): 1-132.

34. Virtanen M, Kivimaki M, Elovainio M, Vahtera J. Selection from fixed term to permanent employ- 
ment: prospective study on health, job satisfaction, and behavioral risks. J Epidemiol Community Health 2002; 56:693-9.

35. Yngwe MA, Diderichsen F, Whitehead M, Holland $\mathrm{P}$, Burstrom B. The role of income differences in explaining social inequalities in self rated health in Sweden and Britain. J Epidemiol Community Health 2001; 55:556-61.

36. Lima-Costa MF, Barreto S, Giatti L, Uchoa E. Desigualdade social e saúde entre idosos brasileiros: um estudo baseado na Pesquisa Nacional pos Amostra de Domicílios. Cad Saúde Pública 2003; 19:745-57.

37. Dachs JNW. Determinantes das desigualdades na auto-avaliação do estudo de saúde no Brasil: análise dos dados da PNAD/1998. Ciênc Saúde Coletiva 2002; 7:641-57.

38. Arber S. Comparing inequalities in females's and males's health: Britain in the 1990s. Soc Sci Med 1997; 44:773-87.

39. Matthews S, Manor O, Power C. Social inequalities in health: are there gender differences? Soc Sci Med 1999; 48:49-60.

40. Stronks K, van de Mheen H, van den Bos J, Mackenbach JP. Smaller socioeconomic inequalities in health among females: the role of employment status. Int J Epidemiol 1995; 24:559-68.
41. Eriksson I, Unden AL, Elofson S. Self-rated health. Comparisons between three different measures. Results from a population study. Int J Epidemiol 2001; 30:326-33.

42. Bergner M, Rothman ML. Health status measures: an overview and guide for selection. Ann Rev Public Health 1987; 8:191-210.

43. Manor O, Matthews S, Power C. Dichotomous or categorical response? Analysing self-rated health and lifetime social class. Int J Epidemiol 2000; 29:149-57.

44. Barsky AJ, Cleary PD, Klerman GL. Determinants of perceived health status of medical outpatients. Soc Sci Med 1992; 34:1147-54.

45. Fylkesnes K, Forde OH. Determinants and dimensions involved in self-evaluation of health. Soc Sci Med 1992; 35:271-9.

46. Appels A, Bosma H, Grabauskas V, Gostautas A, Sturmans F. Self-rated health and mortality in a Lithuanian and a Dutch population. Soc Sci Med 1996; 42:681-9.

47. Krause NM, Jay GM. What do global self-rated health items measure? Med Care 1994; 32:930-42.

Submitted on 04/May/2005

Final version resubmitted on 27/Sep/2005

Approved on 30/Sep/2005 